\title{
EFFECT OF SEQUENTIAL PROGRAMS OF INSECTICIDES ALTERNATIVES AGAINST COTTON BOLL WORMS AND IT'S SIDE EFFECTS ON THE QUANTITY AND QUALITY OF COTTON CROP IN MIDDLE EGYPT
}

\author{
MOHAMED, E. M. ${ }^{1}$, H. A. EL-KADY ${ }^{2}$, E. F. EL - KHAYAT ${ }^{3}$ and S. A. HOSNI ${ }^{1}$ \\ 1. Sids Agric. Res. Station, Plant Protection Res. Institute, ARC, Giza, Egypt. \\ 2. Fac. of Agric., Domyat, Mansora University, Egypt. \\ 3. Fac. of Agric. , Moshtohor, Benha University, Egypt.
}

(Manuscript received 5 July 2012)

\begin{abstract}
The effect of sequential control sprays on cotton bollworms $P$. gossypiella and spiny bollworm, $E$. insulana on the average percent of infestation, the \% reduction of bollworms population, economic losses in cotton yields and average of actual yield was studied.

The $3^{\text {rd }}$ program was the most effective one against cotton bollworms, the seasonal percentages of reduction for spiny and pink bollworms were 92.85 and $94.86 \%$ as compared with the Recommended Ministry Program (RMP), (87.65 and $81.67 \%$ for both insects, respectively).

The $1^{\text {st }}, 2^{\text {nd }}$ and 3 rd programs didn't significantly affect the total common predators in cotton fields while the 4th and 5th programs didn't significantly affect the total common predators as compared with the untreated check, while ministry program effect highly significant on the total common predators on the cotton fields, showing the average percentage of reduction was $65.0 \%$.

The \% economic losses in cotton yields and average actual yield were $4.76 \%$ and 8.45 kentar / fed. as compared with the (RMP), (5.95 $\%$ and 8.55 kentar / fed.), respectively. The seasonal percentage of reduction for pink and spiny bollworms were $86.62,82.22,80.19$, $83.90 \%$ and $86.67,79.44,79.44,70.42 \%$ for the 1st, 2nd, 4th and 5th programs applied to control both insects as compared with the Ministry program (87.65 and $81.67 \%$ ), respectively. The \% economic losses in cotton yields and average actual yield were $(5.37,7.89,10.32$, $8.35 \%$ ) and $8.1,8.05,7.14,7.95)$ kentar / fed. for the 1st, 2nd, 4th and 5th programs applied to control both insects as compared with the ministry program (5.95\% and 8.55 kentar / fed.) respectively.

Concerning the effect of these programs on the chemical properties, oil and protein, it proved no effect .The difference in fiber length at $2.5 \% \mathrm{SL}$ affected by these programs. The differences in fiber length (Pressley index) did not affected by these programs. The highest value of micronaire reading (4.53 micronaire unit) resulted from $5^{\text {th }}$ program as a compared with the Ministry Program (4.37 miconaire unit).
\end{abstract}




\section{INTRODUCTION}

Cotton is the most important fiber crop all over the world. In Egypt, cotton is a very important crop that is cultivated mainly for fibers in industry and seeds for oil which is of great value.

During the last years, cotton plants in Egypt have been attacked by numerous pests from planting till harvest, including sap sucking pests, cotton leaf worms and cotton bollworms, causing great damage to plants and crop yield. All the plant parts may be attacked, but the most serious pests primarily attack the fruiting portions, squares, flowers and green bolls, reducing both quantity and quality of the harvested lint and seeds, during the late season. Cotton plants greatly suffer from infestation with pink bollworm, Pectinophora gossypiella (Saunders) and spiny bollworm, Earais insulana (Boisd).

The main way for controlling these pests is still by using chemical insecticides. There are many problems which have appeared with the repeated use of insecticides including hazards to man and his animals by environmental pollution and also, the appearance of resistant strains of insect pests to insecticides ( Nassef and Watson 1999 ).

Recently, the Ministry of Agriculture began to implement a new strategy for the more precise use of pesticides in pest control. Integrated pest / crop management IPM / ICM includes a total system of approaches for suppression the population density of cotton key pests to below the economic threshold level. Mass - production and release of trichogramma egg parasitiods is regarded as a promising approach to reduce egg hatching and subsequent crop damage by cotton bollworms. (Abd El - Hafez et. al. 2004, Mohamed, 2004 and Mohamed et. al. 2010).

Therefore, using new approaches in pest management systems is highly encouraged. Alternative of conventional insecticides with bioregional compounds are currently being investigated. these are used compatible with integrated pest management.

The aim of this study were carried out to evaluate the effectiveness of sequential programs, pesticides alternatives against cotton bollworms, (pink and spiny bollworms) infesting cotton green bolls and it's side effects on some important predators in cotton fields, also, the quantity and quality of cotton crop.

\section{MATERIALS AND METHODS}

Field experiments were carried out to evaluate some new approaches to integrated control of cotton bollworms in middle Egypt, as follow. 


\section{Biocides}

1.1. Protecto: $9.4 \%$ W.P.: Biological insecticides based on Bacillus thuringiensis is subsp. Kurstaki, it contains $9.4 \%$ Lepidopteran active toxin produced by the Plant Protection Res. Inst., A.R.C. The rate of application was $300 \mathrm{gm} /$ fed.

1. 2. Spintor 24 SC (Spinosad): The spinosyns obtained from a culture of the actinomycete Saccharopolyspora spinosa containing a naturally occurring mixture of spinosyn $A\left(\mathrm{C}_{41} \mathrm{H}_{65} \mathrm{NO}_{10}\right)$ and spinosyn $D\left(\mathrm{C}_{42} \mathrm{H}_{67} \mathrm{NO}_{10}\right)$. The insecticide was introduced by Dow Agro Sciences for control lepidopterous pests in cotton under the trade name (Tracer). The rate of application was $50 \mathrm{~cm}^{3} /$ fed.

1. 3. Spinetoram (radiant $\mathbf{1 2} \% \mathbf{S C}$ ): It consists of a mixture of major component (3-ethoxy-5,6 - dihydro.spinosyn J) and the minor one (3-ethoxy. Spinosyn L) at a rate of $25 \mathrm{~cm}^{3}$ /fed.. Both chemicals were produced by Dow Agro Sciences Chemical Co.

\section{Synthetic chemical insecticides}

2.1 Dursban insecticide (Chlorypyrifos) $\mathbf{4 8 \%}$ E.C: The chemical name is 0,0 diethyl 0 -3,5,6-trichloro-2-pyridyl phosphorothioate. The rate of application was 1000 $\mathrm{cm}^{3} /$ fed.

2.2 Fenvalerate 5\% E.C(Sumi- alpha): A synthetic pyrethroid. Its chemical name is: Cyano (3-phenoxyphenyl)methyl 4-chloro-a-(1-methylethyl) benzeneacetate. The rate of application was $600 \mathrm{~cm}^{3} /$ fed.

2.3 Larvin insecticide (Thiodicarb) $80 \%$ D.F: Its chemical name is:

3,7,9,13-tetramethyl-5,11-dioxa-2,8,14-trithia-4,7,9,12-tetra-azapentadeca-3,12diene-6,10-dione. The rate of application was $460 \mathrm{gm} / \mathrm{fed}$.

\section{The Trichogramma evanescens (Westood) parasitoid}

\subsection{Rearing technique}

T.evanescens was reared on the grain moth, Sitotroga cerealla (Oliv.) eggs in laboratory . The egg parasitoids were released as mature pupa into the field using a release card that protects them from predators and unfavorable weather. The release card was prepared in the laboratory, this card contains three strips of paper $1 \times 1 \mathrm{~cm}$ that contain parasitoid pupa about 300-350 pupa / a strip of paper at three different stages of development 1, 2 and 3 days before emergence. Cards were hanged manually before the sunset on the plant at about $50 \mathrm{~cm}$ above the ground. Twenty two cotton plants / fed. were selected to serve as a release points. The distance between these points was 14 meter and started 7 meter from the edges of the field. 
The compounds were applied consequently in a sequence

\begin{tabular}{|c|c|c|c|}
\hline Programs & $\begin{array}{l}\text { Treatment } \\
\text { time }\end{array}$ & $\begin{array}{l}\text { Sequence of } \\
\text { treatments }\end{array}$ & $\begin{array}{c}\text { Rate of } \\
\text { application / fed. }\end{array}$ \\
\hline $\mathbf{1}^{\text {st }}$ program & \multirow{2}{*}{$\begin{array}{l}\text { With 3\% } \\
\text { infestation }\end{array}$} & Spintor $\rightarrow$ Tricho $\rightarrow$ Radiant & $50 \mathrm{~cm}^{3} \rightarrow 22 \mathrm{card} \rightarrow 50 \mathrm{~cm}^{3}$ \\
\hline $2^{\text {nd }}$ program & & Radiant $\rightarrow$ Spintor $\rightarrow$ Protecto & $50 \mathrm{~cm}^{3} \rightarrow 600 \mathrm{~cm}^{3} \rightarrow 460 \mathrm{gm}$ \\
\hline $3^{\text {rd }}$ program & \multirow{3}{*}{ with $1^{\text {st }}$ flower } & Tricho $\rightarrow$ Tricho $\rightarrow$ Spintor & 22 card $\rightarrow 22$ card $\rightarrow 50 \mathrm{~cm}^{3}$ \\
\hline $4^{\text {th }}$ program & & Tricho $\rightarrow$ Tricho $\rightarrow$ Protecto & 22 card $\rightarrow 22$ card $\rightarrow 300 \mathrm{gm}$ \\
\hline $5^{\text {th }}$ program & & Tricho $\rightarrow$ Tricho $\rightarrow$ Tricho & 22 card $\rightarrow 22$ card $\rightarrow 22$ card \\
\hline $6^{\text {th }}$ program & $\begin{array}{l}\text { With 3\% } \\
\text { infestation }\end{array}$ & $\begin{array}{c}(\text { RPMA }) \\
\text { Dursban } \rightarrow \text { Sumi-alpha } \rightarrow \text { Larvin }\end{array}$ & $1000 \mathrm{~cm}^{3} \rightarrow 600 \mathrm{~cm}^{3} \rightarrow 400 \mathrm{gm}$ \\
\hline Untreated ched & --- & --- & -- \\
\hline
\end{tabular}

Tricho. $=$ Trichogramma evanescens

In these programs, the sequential first and second programs started with $3 \%$ green infestation. The first spray was Spintor and Radiant. The second spray was replaced by three releasing of egg parasitoids $T$. evanescens . The third spray was Radiant and Spintor. The sequential third and forth programs were started with the first flower. The numbers of releasing were six releasing, respectively. The third spray was Protecto and Spintor. The sequential fifth program started with the first flower until the end of season. The number of releasing of egg parasitoids were 8 releasing, respectively.

The percentages of infestation by pink bollworm and spiny bollworm, the population of the common predators on cotton fields, \% economic loss and yield production were recorded compared with the Ministry Program.

\section{Cotton yield losses}

To determine the potential yield losses at the end of each cotton season, the economic loss percentages were determined according to ( Hosny et. al. 1967).

\section{Fiber properties and some chemical contents}

* Fiber length, measured using the Digital fibro graph Model 530 expressed as 2.5 and 50\% span length according to the standard method of May and Bridges 1995.

* Fiber strength: determined by in pressley index using the pressley instrument as reported by A.S.T.M. (1979).

* Fiber fineness (Mic): It was measured by micronaire apparatus and expressed in stander micronaire units (May and Bridges 1995). All fiber properties tested were measured under the standard conditions of temperature $\left(21+1 \mathrm{C}^{\circ}\right)$ and relative humidity\% $(65+2$ R.H.\%) at the laboratory of the Cotton Technology Research Division, Cotton Res. Institute in Giza. 
* Protein and oil percentages in mature seeds were calculated by multiplying the total nitrogen value by $6.25 \%$ as stated by A.O.A.C. (1985).

\section{RESULTS AND DISCUSSION}

\section{Effect of sequential control sprays on cotton bollworms}

To evaluate the best approaches that had been tested in 2006 and 2007 seasons for cotton bollworm management. An experiment was conducted in 2008 season to test some different selected promising programs under the concept of IPM and compared them with the Ministry program. According to the obtained results of 2006 and 2007seasons, cotton Giza 80 was planted on the best date $\left(13^{\text {th }}\right.$ March). Six sequences of control agents were chosen for their efficiency against cotton bollworms and safety to the natural enemies. These control agents were as follows:

Data presented in Table 1 and illustrated in Fig.1 show the effect of different concepts and approaches on the average percent of infestation, the \% reduction of bollworms population, economic losses in cotton yields and average actual yield. The results showed that the application of the best approaches tested in 2006 and 2007 revealed promising results as follows:

Table 1. Effect of sequence control sprays on the average percent of bollworms infestation, average percent of reduction, average \% of economic loss and average actual yield in cotton fields at Sids Res. station during 2008 season.

\begin{tabular}{|c|c|c|c|c|c|c|}
\hline \multirow{2}{*}{$\begin{array}{l}\text { Sequential } \\
\text { Programs }\end{array}$} & \multicolumn{4}{|c|}{ Av. Seasonal \% reduction } & \multirow{2}{*}{$\begin{array}{c}\text { \% economic } \\
\text { losses }\end{array}$} & \multirow{2}{*}{$\begin{array}{c}\text { Average } \\
\text { actual } \\
\text { yield } \\
\text { kentar / } \\
\text { fed. }\end{array}$} \\
\hline & PBW & SBW & $\begin{array}{c}\text { PBW } \\
+ \\
\text { SPW }\end{array}$ & Predators & & \\
\hline $1^{\text {st }}$ program & $86.62 \mathrm{~b}$ & $86.67 \mathrm{a}$ & $87.88 \mathrm{~b}$ & $25.16 \mathrm{~b}$ & $5.37 \mathrm{c}$ & $8.10 \mathrm{a}$ \\
\hline $2^{\text {nd }}$ program & $82.22 \mathrm{C}$ & $79.44 \mathrm{~b}$ & $82.31 \mathrm{c}$ & $37.63 \mathrm{~b}$ & $7.89 \mathrm{c}$ & $8.05 \mathrm{a}$ \\
\hline $3^{\text {rd }}$ program & $92.85 \mathrm{a}$ & $94.86 \mathrm{a}$ & $93.64 \mathrm{a}$ & $23.55 \mathrm{c}$ & $4.76 \mathrm{c}$ & $8.45 \mathrm{a}$ \\
\hline $4^{\text {th }}$ program & $80.19 \mathrm{bc}$ & $79.44 \mathrm{~b}$ & $80.79 \mathrm{c}$ & $10.35 \mathrm{~d}$ & $10.32 \mathrm{~b}$ & $7.14 \mathrm{a}$ \\
\hline $5^{\text {th }}$ program & $83.90 \mathrm{~b}$ & $70.42 \mathrm{c}$ & $81.56 \mathrm{c}$ & $4.85 \mathrm{~d}$ & $8.35 \mathrm{c}$ & $7.95 \mathrm{a}$ \\
\hline $6^{\text {th }}$ program & $87.65 \mathrm{~b}$ & $81.67 \mathrm{~b}$ & $86.79 \mathrm{~b}$ & $65.0 \mathrm{a}$ & $5.95 \mathrm{c}$ & $8.55 \mathrm{a}$ \\
\hline Untreated check & 0.00 & 0.00 & 0.00 & 0.00 & $24.50 a$ & $3.65 \mathrm{~b}$ \\
\hline L.S.D 5\% & 3.91 & 6.8 & 4.91 & 12.95 & 5.3 & 4.2 \\
\hline
\end{tabular}

$\rightarrow$ The values marked with the same letter are not significantly different according to $\mathrm{L}$. S. D. test at $5 \%$ level. 
The $3^{\text {rd }}$ program was the most effective program against cotton bollworms. The seasonal percentages of reduction for pink and spiny bollworms were 92.85 and $94.86 \%$ as compared with the Recommended Ministry Program (RMP), (87.65 and $81.67 \%$ for both insects, respectively). The seasonal percentage of reduction for pink and spiny bollworms were $86.62,82.22,80.19,83.90 \%$ and $86.67,79.44$, $79.44,70.42 \%$ for the $1^{\text {st }}, 2^{\text {nd }}, 4^{\text {th }}$ and $5^{\text {th }}$ programs applied to control both insects as compared with the Ministry program (87.65 and $81.67 \%$ ), respectively.

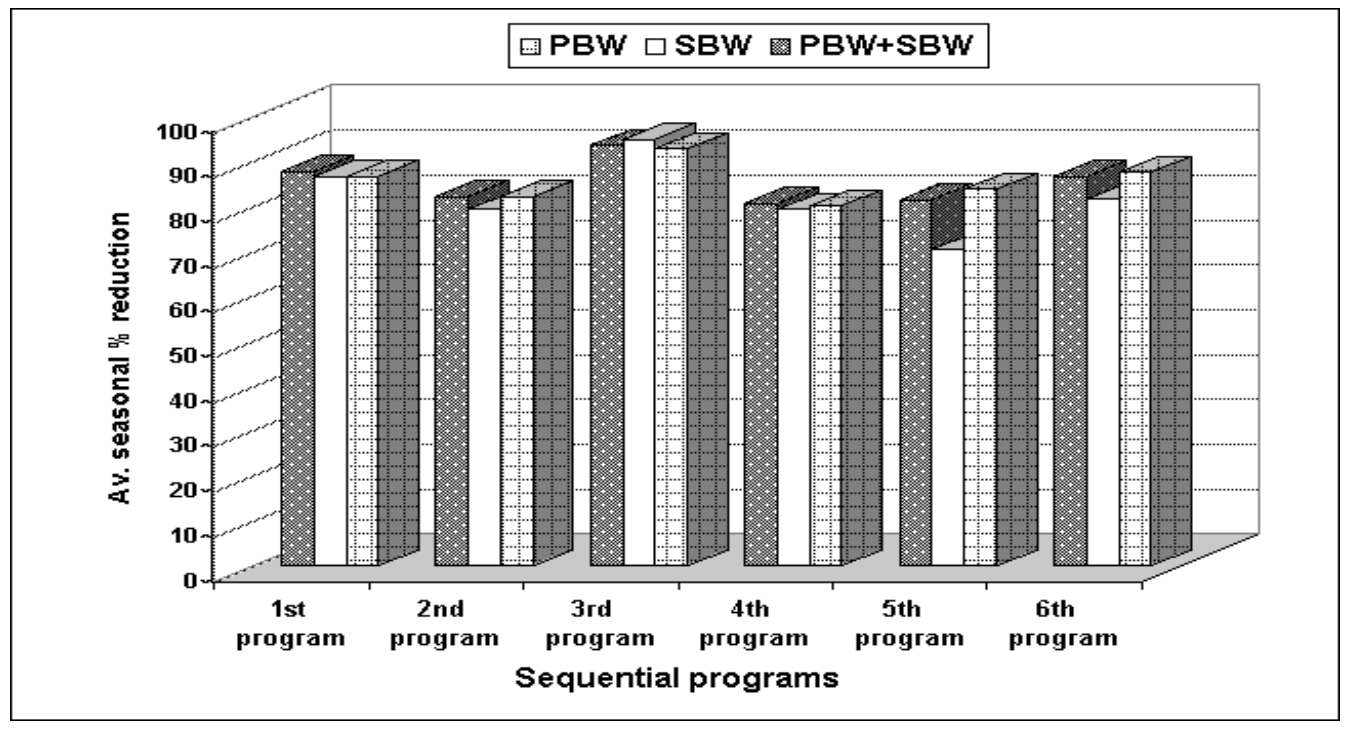

Fig. 1. Effect of sequence control sprays on the average percent of bollworms infestation, average percent of reduction, in cotton fields at Sids Res. station during 2008 season

\section{Effect of sequence control sprays on cotton bollworms on six main predators commonly found in cotton fields.}

The role of the natural enemies has to be taken into account in any integrated program for pest control. Therefore, entomologists have recorded many insect predators as Chrysoperla carnea, Coccinella spp. Orious spp. Peaderus alfierii, Scymnus spp., and true spiders in cotton fields.

Data presented in Table 1 and illustrated in Fig. 2 show the effect of different concepts of IPM on six main predators common in cotton fields. The $1^{\text {st, }} 2^{\text {nd }}$ and $3^{\text {rd }}$ programs reduced the total common predators in cotton fields. The \% reduction were $25.16,37.63$ and $23.55 \%$, respectively as a compared with the ministry program $(65 \%)$, while the $4^{\text {th }}$ and $5^{\text {th }}$ programs were the least effective treatments on the total common predators. The Ministry program effect highly significant on the total common predators on the cotton fields, the average percentage of reduction was $65.0 \%$. 


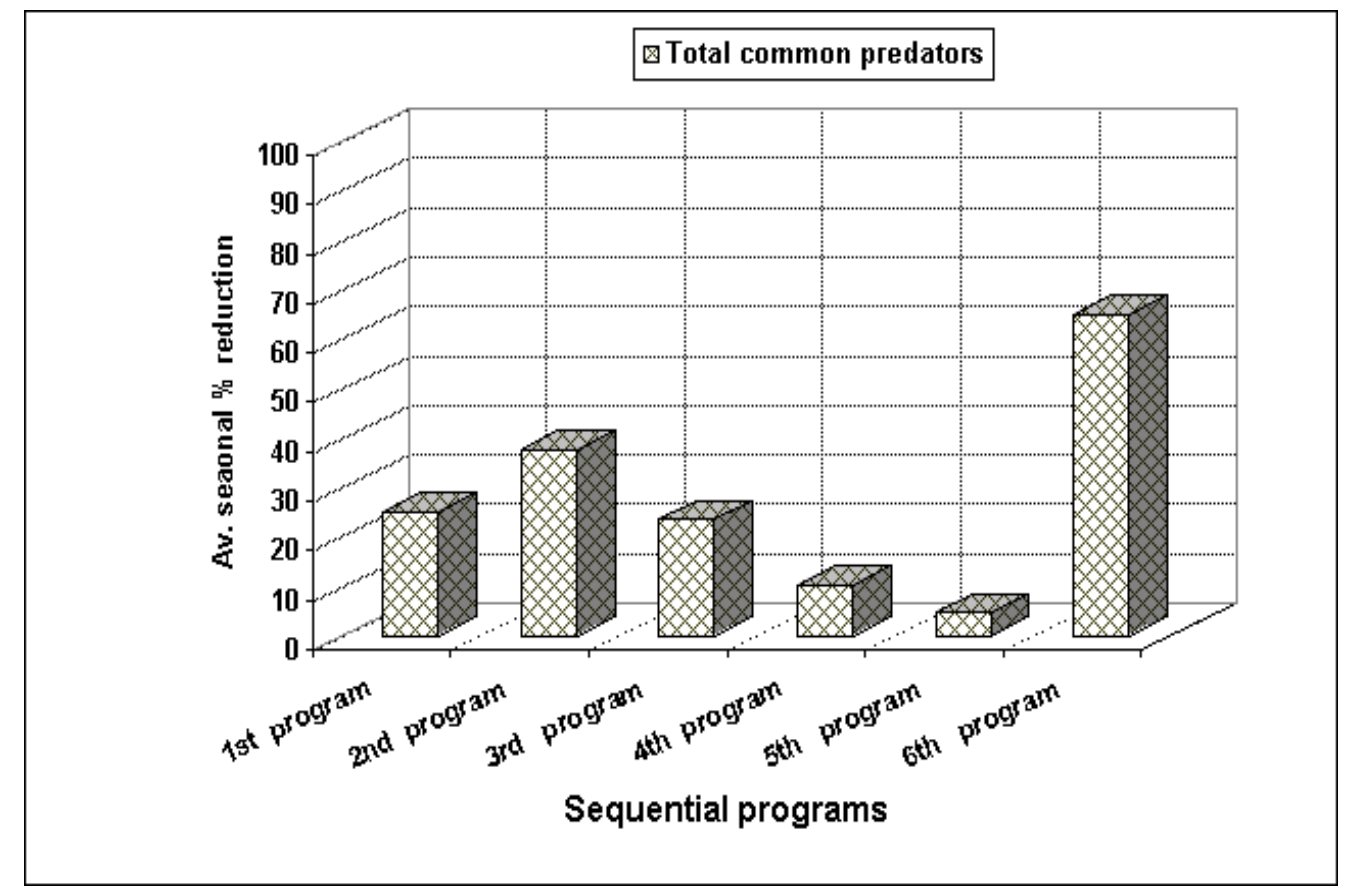

Fig. 2 . Effect of sequence control sprays on cotton bollworms on six main predators commonly found in cotton fields at Sids Res. station during 2008 season.

These results are agree with those obtained El- Husseini et. al. (1996), mentioned that the common predators migrate from clover into cotton fields and reached its maximum population in July.Also, Hegab (2002) stated that the three tested spray programmes had highly significant adverse effects on the population density of Orius spp.recorded 52.95 and $40.35 \%$ reduction during two seasons, respect. Recently, Yousif-Khalil et. al. (2008) found that chlorpyrifos caused the highest degree of \% reduction for all investigated predators, followed by spinosad and methoxyfenozide.

\section{Effect of sequence control sprays on the average \% of economic loss and average actual yield in cotton fields}

Data presented in Table 1 and illustrated in Fig.3 show the effect sequence control sprays on the average \% of economic loss and average actual yield in cotton fields. 


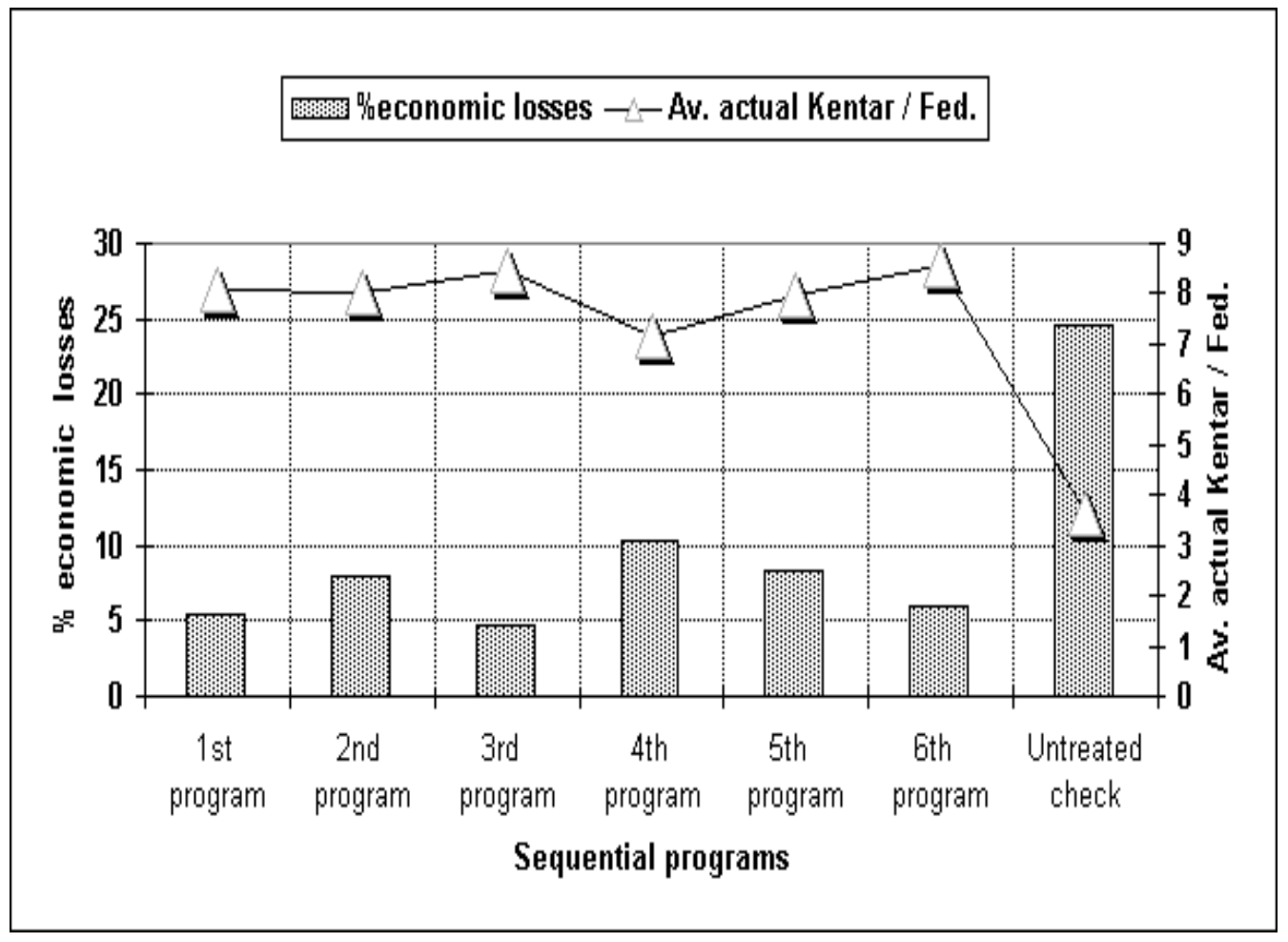

Fig. 3. Effect of sequence control sprays on the average \% of economic loss and average actual yield in cotton fields at Sids Res. station during 2008 season

The $\%$ economic losses in cotton yields and average actual yield for the $3^{\text {rd }}$ program were $4.76 \%$ and 8.45 kentar / fed. as compared with the (RMP), (5.95\% and 8.55 kentar / fed.), respectively. The \% economic losses in cotton yields and average actual yield for the $1^{\text {st }}, 2^{\text {nd }}, 4^{\text {th }}$ and $5^{\text {th }}$ programs were $(5.37,7.89,10.32$, $8.35 \%)$ and $(8.1,8.05,7.14,7.95$ kentar / fed.) as compared with the ministry program ( $5.95 \%$ and 8.55 kentar / fed.), respectively.

\section{Effect of sequence control sprays on cotton properties}

The data presented in Tables 2 show the effect of different concepts and approaches on some cotton properties (chemical and fiber properties). Concerning the effect of these programs on the chemical properties, (oil and protein) do not affected by these programs. The difference in fiber length at $2.5 \% \mathrm{SL}$ affected by these programs. The differences in fiber length (Pressley index ) did not affected by these program. As shown in Table (2), the difference in fiber fineness (micronaire reading ) as affected by programs. The highest value of micronaire reading (4.53 micronaire unit) resulted from $5^{\text {th }}$ program as a compared with the Ministry Program (4.37 miconaire unit). 
Table 2. Effect of sequence control sprays on cotton properties and Ministry program on some cotton characters (chemical and fiber properties) during 2008 season.

\begin{tabular}{|c|c|c|c|c|c|c|c|}
\hline \multirow[t]{2}{*}{ Characters } & \multicolumn{3}{|c|}{ Chemical Properties } & \multicolumn{4}{|c|}{ Fiber properties } \\
\hline & $\begin{array}{c}\text { Protein } \\
\%\end{array}$ & Oil \% & $\begin{array}{l}\text { Gossy } \\
\text { pol \% }\end{array}$ & $\begin{array}{c}\text { Fiber } \\
\text { length } 2.5 \\
\% \text { SL } \\
\end{array}$ & $\begin{array}{c}\text { Uniformity } \\
\text { ratio }\end{array}$ & $\begin{array}{l}\text { Pressle } \\
y \text { index }\end{array}$ & $\begin{array}{c}\text { Micron } \\
\text { aire } \\
\text { reading }\end{array}$ \\
\hline $1^{\text {st }}$ program & 17.20 & 19.60 & $3.22 \mathrm{a}$ & $32.20 \mathrm{a}$ & $85.70 \mathrm{a}$ & 8.67 & $3.77 \mathrm{~b}$ \\
\hline $2^{\text {nd }}$ program & 17.97 & 21.20 & $2.64 \mathrm{a}$ & $32.07 \mathrm{a}$ & $84.37 \mathrm{a}$ & 8.50 & $4.33 \mathrm{a}$ \\
\hline $3^{\text {rd }}$ program & 18.75 & 19.60 & $3.93 \mathrm{a}$ & $31.80 \mathrm{~b}$ & $84.47 \mathrm{a}$ & 9.83 & $4.27 \mathrm{a}$ \\
\hline $4^{\text {th }}$ program & 17.97 & 19.60 & $3.73 \mathrm{a}$ & $32.43 \mathrm{a}$ & $85.70 \mathrm{a}$ & 8.83 & $4.13 \mathrm{~b}$ \\
\hline $5^{\text {th }}$ program & 21.10 & 21.35 & $3.93 \mathrm{a}$ & $31.97 \mathrm{~b}$ & $85.87 \mathrm{a}$ & 9.50 & $4.53 \mathrm{a}$ \\
\hline $6^{\text {th }}$ program & 18.75 & 22.40 & $2.83 \mathrm{~b}$ & $31.63 \mathrm{~b}$ & $85.00 \mathrm{a}$ & 8.50 & $4.37 \mathrm{a}$ \\
\hline Untreated check & 20.31 & 21.06 & $2.67 \mathrm{~b}$ & $31.03 b$ & $83.23 \mathrm{~b}$ & 9.00 & $4.37 \mathrm{a}$ \\
\hline L.S.D $5 \%$ & n.s & n.s & 1.07 & 0.9 & 0.94 & n.s & 0.13 \\
\hline
\end{tabular}

- The values marked with the same letter are not significantly different according to L. S. D. test at $5 \%$ level.

These results are agree with Sharma and Agarwal (1992) studied the effect of insecticidal application Fenvalarate and Cypermethrin on the fibre quality and seed cotton. The results indicated that a higher oil content in seeds of the cotton gave higher fibre length, fibre strength at the $50 \%$ boll formation stage. In this respect, ELTabbakh (2002) reported that the number of bolls /plant and seed cotton yield per plant were higher when treated with insecticides, Actellic, Durspan and Larvin . Osman et. al. (2006) reported that oil and protein content was increasing significantly in cotton seed of Barakat -90 when treated with Chlorpyrifos. But there was no significant in cultivar Barac -67. Jiang et al.(2009) studied the effect of Confider SL $20 \%$ applied by different methods on growth, development and fibre quality of cotton . Treatment of Confider SL $20 \%$ applied in watering root shows better effects on cotton fibre qualities, especially in fibre length, length uniformity, elongation, the index of short fibre as well as textile index. The treatments Confider SL $20 \%$ foliar application display the good function on cotton development, whereas the treatments Confider SL $20 \%$ applied in watering root obviously improve the fibre quality . 


\section{REFERENCES}

1. Abd El - Hafez, A., A. S. Afifi, A. A. Moustafa and D. A. Ahmed. 2004. Toxicological and biological effects of some biocides on pink bollworm, Pectinophora gossypiella (Saund.). $2^{\text {nd }}$ international Conference, Plant Protection Res. Insti., Egypt, 21- 24 December 319- 326.

2. A.O.A.C. Association of Official Agriculture Chemists. 1985. Official methods of analysis 14th Ed., Published Washington, Dc., U.S.A.

3. A.S.T.M. 1979. American Society for Testing and Materials. Standard on Textile Materials (D 1448-59) and D 1445-67). The Society Washington, Philadelphia, U.S.A.

4. El- Husseini, M.M., E.A.Agamy and H.E. Abou-Bakr. 1996. Manipulation of insect predators to migrate from clover into cotton fields as contribution to organic cotton production. Egypt. J. Biol. Control , 6 (20): 207-211.

5. EL- Tabbakh, S.S. 2002. Effect of some fertilizer and insecticidal treatments on growth, yield, yield components and quality of two cotton cultivars . Elexandria J. Agric. Res. 47 (2) 61-72.

6. Hegab, M. E. M. 2002. Studies on bollworms infesting cotton in Sharkia Governorate, Egypt .M. Sc. Thesis, Zagazig Univ., 207 pp. Henderson, C. F.

7. Hosny, M. M. , M. A. A. Assem and S. A. A. Nasr. 1967. Entomological and Zoological Agriculture pests pp. 563-565 First ed. Dar- El Maaref , Egypt. (in Arabic).

8. Jiang, Y.T.,Ying, M.D. and Y. BaoHuan. 2009. The effect of Confider SL $20 \%$ applied by different methods on growth, development and fiber quality of cotton. (Chiness). Xinjiang Agric. Sci. 46 : (3) 574-577.

9. May, O.L. and B.C. Bridges. 1995. Breeding cotton for conventional and late planted production system. Crop Sci., (32):132-136.

10. Mohamed, E.M. 2004. New Approaches for control of cotton bollworms. Ph. D Thesis Department of Economic Entomology and Pesticides Faculty of Agriculture Cairo University.

11. Mohamed, E.M., Hanan, F. Abdel-Hafez and Mahasen, A. Abdel-Aziz. 2010. Effect of adding some chemical additives on increasing the potency and residual effect of Bacillus thuringiensis against the cotton leafworm, Spodoptera littoralis (Lepidoptera: Noctuidae). Egypt. J. Agric. Res., 88(1): 103-112.

12. Nassef, M. A. and W. M. Watson. 1999. Sequential spray schedules of insecticides to control bollworms as a target pests in addition to certain sap sucking suckers as non- target pests in cotton fields. Egypt. J. Agric. Res., 77 (3): 1155-1162. 
13. Osman, G. A., A. I., Mustafa and A. O. Abdelbagi. 2006. Effect of Chlorpyrifos on oil, protein, minerals and antinutritional factors of cotton seeds. J. of Food Technol 4 (1): 32-36.

14. Sharma. J. P. and R. A. Agarwal. 1992. Effect of insecticidal application on the fibre quality, seed cotton and carry over of Pectinophora gossypiella (Saund) J. of Insects Sci. 1992. 5: 2,153-156.

15. Yousif-Khalil, S.I., S. A. A. Raslan, Ola I. Hegab and Omnia S. Abd-Elsttar. 2008. Efficiency of spinosad and runner against pink bollworm and predators population on cotton fields .Zagazig J. Agric. Res., 35 (2): 407-422. 


\section{تاثير برامج متتابعة لبائل المبيدات ضد ديدان لوز القطن وآثارها الجانبية على كمية

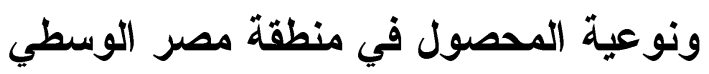

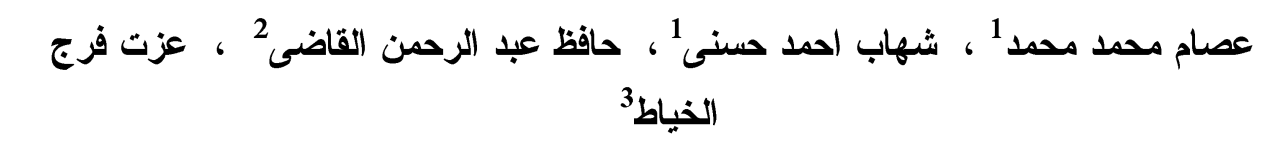

$$
\begin{aligned}
& \text { ا . محطة بحوث سدس - معهز بحوث وقاية النباتات - مركز البحوث الزراعبة - الجيزة - مصر } \\
& \text { r ـ قسم الحشرات الاقتصادية - كلية الزراعة بدمياط - جامعة الدنصورة }
\end{aligned}
$$

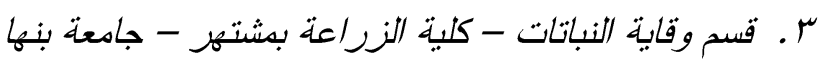

أجريت تجربة حقلية استخدم فيها أفضل النتائج المتحصل عليها في موسمي 2006 و

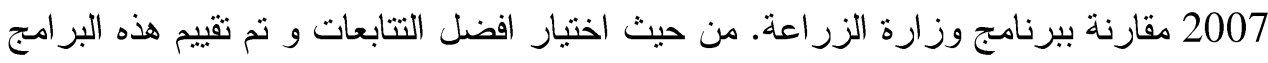

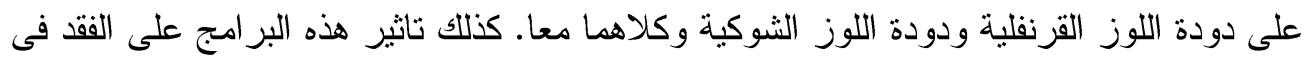

المحصول وكمية الإنتاج وخصائص القطن من نسبة الزيت ونسبة البروتين وخصائص التيلة.

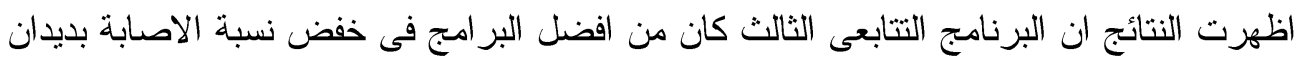

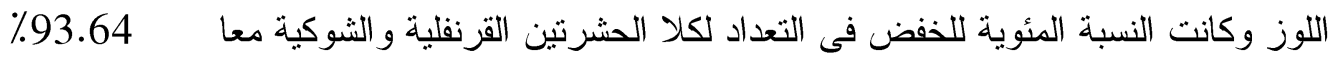
بالمقارنة مع برنامج وزارة الزر اعة الموصى به (86.79 \% لكل من الحشرنين). وكانت النسبة

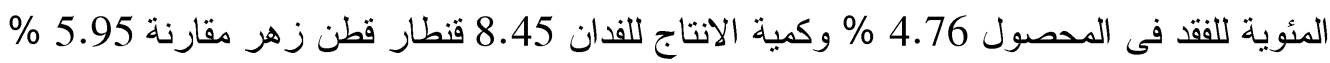

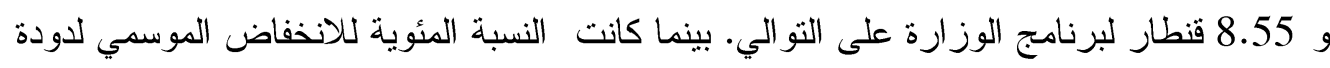

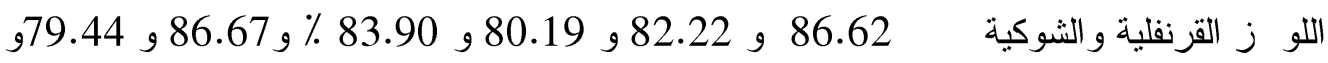
79.44 و 70.42\% للإنامج الأول و الثاني و الر ابع و الخامس مقارنة مع برنامج الوزارة ( 87.67 .65

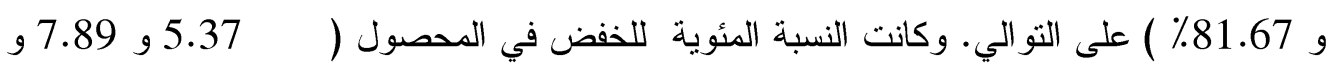

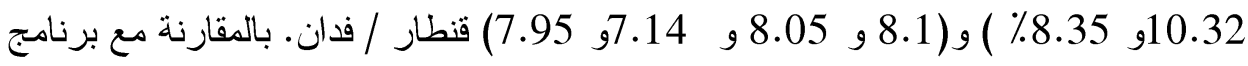

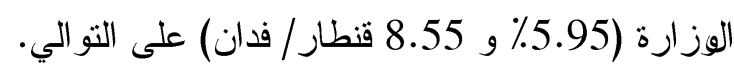

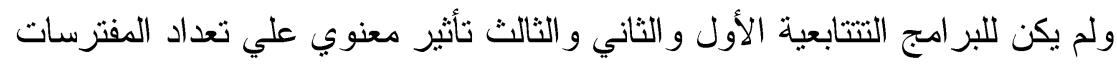

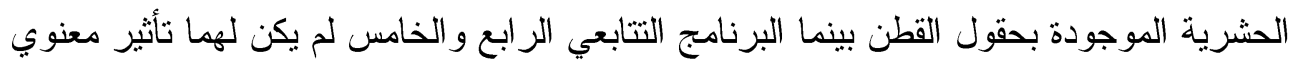

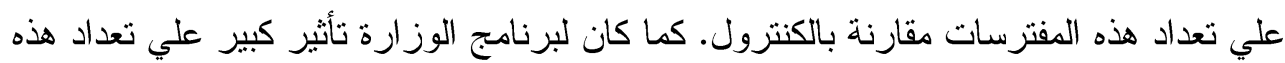

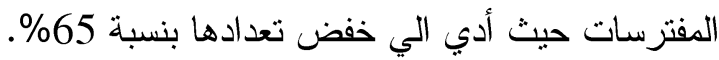
ومن ناحية أخرى تم در اسة هذه التتابعات على بعض خصائس القطن (الخواص الكيميائية و الألياف). فيما يتعلق بأثر هذه البر امج على الخصائص الكيميائية، (نسب الزيت و والبروتين و الجو هون

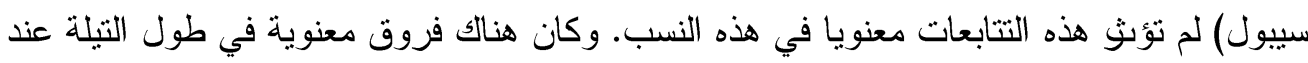
2.5 \% ومعامل انتظام الطول و النعومة و المتمثلة في قراءة الميكرونير حيث كان أفضل التتابعات هو التتابع الخامس حيث بلغت قر اعة الميكرونير 4.53 مقارنة 4.37 لبرنامج الوزارة. 